\title{
歯肉に発生した細網肉腫の1例
}

岡 伸光 - 玉井健三・福田順子 - 瀬尾永樹 - 藤井佐代子 - 林 俊郎

\section{Reticulum cell sarcoma of gingiva; A case report}

Nobumitsu OKa - Kenzo TamaI - Junko Fukuda - Nagaki Seo

Sayoko FujII - Toshiro Hayashi

\section{序}

口证領域に括ける，細網肉腫の発現例は，かなり多 〈1),それらのうち，多くは口腔所属のリンパ節ないし， リンハ腺装置を有する組織より発生している，一方䫇骨 中心性化発生する骨䯣性細網肉腫る，稀少例ではあるが 報告されている.最近われわれは，上下额前歯部歯肉よ り原発したと考兄られる症例に遭遇し，交献的考察によ ク，骨髄，リンパ性組織に由来しない歯肉組織に原発し た報告例が，きわめて少ない2，3)ので，ここに本例を追 加報告する.

\section{症}

例

患 者: 67 才, 女性, 主婦.

初診: 昭和 45 年 4 月回.

主 訴：上下顎前歯部歯肉の膨隆および勗㗖障害.

既往歴：8年前, 転倒により, 右側大腿骨骨折.

家族歴：本症之関連を有する事項なし。

他科疾患: 約 15 年前より現在まで高血圧症のため治 療中. 左右側難聴.

現病歴：䄪 20 年前仁作製した有床義歯を現在まで使

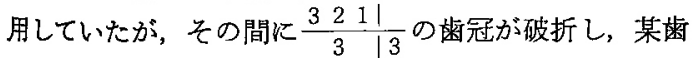
科医院にて，残根上に義歯が追加されている. 本年 3 月 初旬侄り，上下䫇前歯部の肉肉脸に気付き，その 偅脤は急速に增大し，自発痛を伴い，咀嚼不全となった ため，当科に受諪した。

現 症: 全身所見; 体格中等度, 栄盖状態良好. 大腿 骨々折の後遺症として, 軽度の歩行障害を認める。右側 は中等度, 左側は高度の難聴が認められた。

口憖内所見写真 1，2 に示すごとく，上下顎前歯の歯 肉に不定形の指頭大の增殖が見られ，表面には一部潰瘍

金沢大学医学部付属病院歯科口腔外科 (主任: 岡伸光助教授) Clinic of Dentistry \& Oral surgery, School of Medicine, Kanazawa Univercity (Chief ; Assist. Prof. Nobumitsu Oka)

受付 昭和 46 年 7 月 6 月

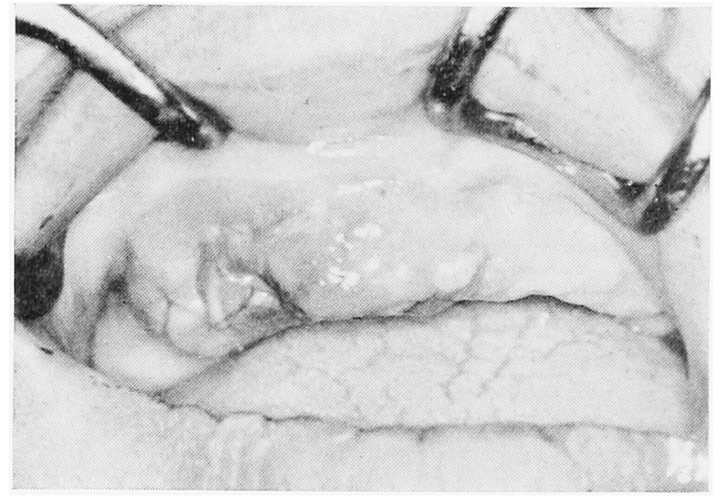

上 顎

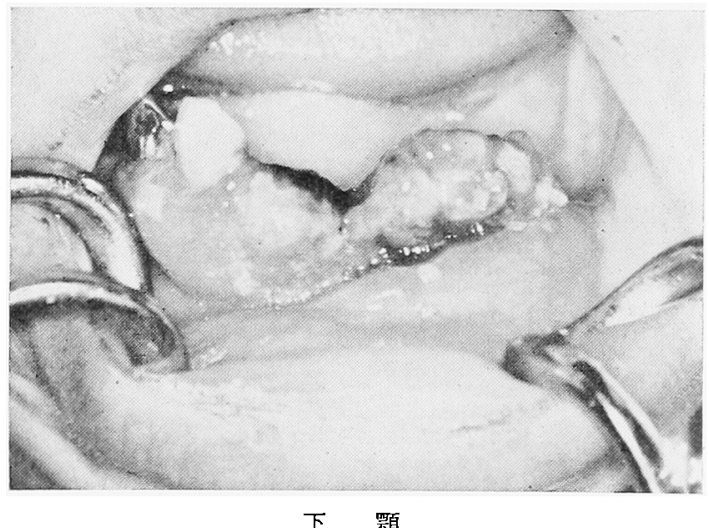

写真 1,2 初診時口腔内所見

形成があり，点在性の出血も見られる．畽瘤は触䛦では 軟かく，弾性にとみ，圧痛を訴える。齿牙は $\frac{3211}{432 \mid 3}$ が 残存し， $\frac{3211}{213}$ は残根状態となっている. その他の煩 粘膜, 口蓋, 舌などには異常を認めない，所属リンパ節 の触診では, 碩下, 舌下, 顎下, 頸部, 鑜骨上下部のリ ンパ節の腯脹は，いずれも触知することが出来なかっ た. 
X線写真所見；上下罘 Panorama 撮影により影骨, 歯槽突起部を精查したが， $\frac{321 !}{2}$ の残根々尖部に一部 暗影を認めるのみで, 特に骨葡性腫湟を疑わしめる所見 はない、な括，胸部，頭部などの全身的 X線写真にも異 常を認めていない。

臨床検查：表 1 に示すと拈りで，血液検查に括いて， 白血球が $10500 / \mathrm{ml}$ で增加がみられ，血液像で好中球の 5ち，桿状，分葉核とも多く、リンパ球るやや增加して いる. 赤沈は 1 時間值 $50 \mathrm{~mm}, 2$ 時間値 $80 \mathrm{~mm}$ で, 一 応悪性腫湯を豖わせる值を示している.

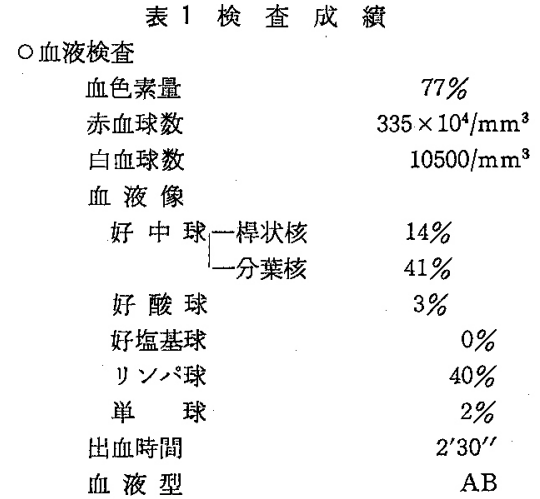

\begin{tabular}{|c|c|}
\hline 赤＼cjkstart沈 & $1 \mathrm{~h} \cdot 50 \mathrm{~mm}, 2 \mathrm{~h} \cdot 80$ \\
\hline $\begin{array}{l}\text { O尿 検 査 } \\
\text { O梅䓯血清反 }\end{array}$ & 研白 $(-)$, 糖 $(-)$ \\
\hline O血液生化学桧査 & 特に異常を認め \\
\hline
\end{tabular}

その他，尿，血液生化学検查で性正常であった。

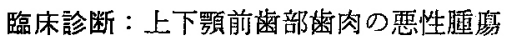

病理組織学的検査：第 1 回目の biopsy は, 初診時に

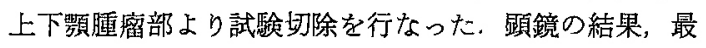

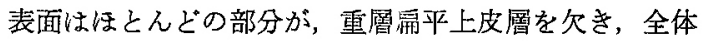
が好酸性均一な Cell debrisよりなる壞死層に被われて いる，その深部では，核小体明膫で，核質の明るい円形， 隋円形核をもつもの，あるいは核の潭染する多形角を持

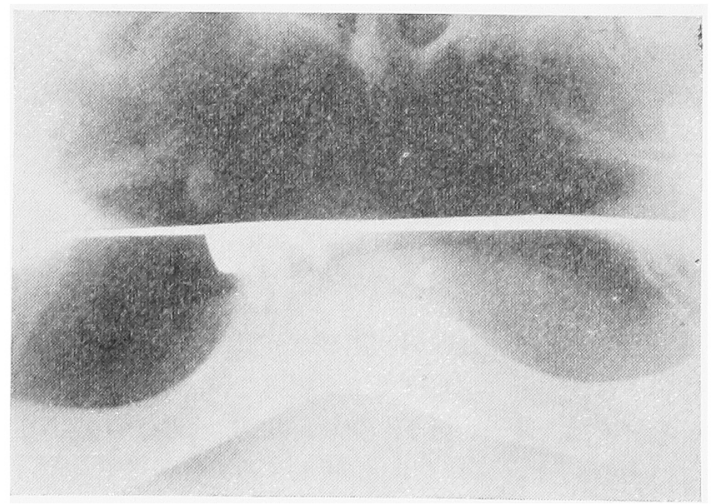

写真 3 上下顎骨レ悢所見

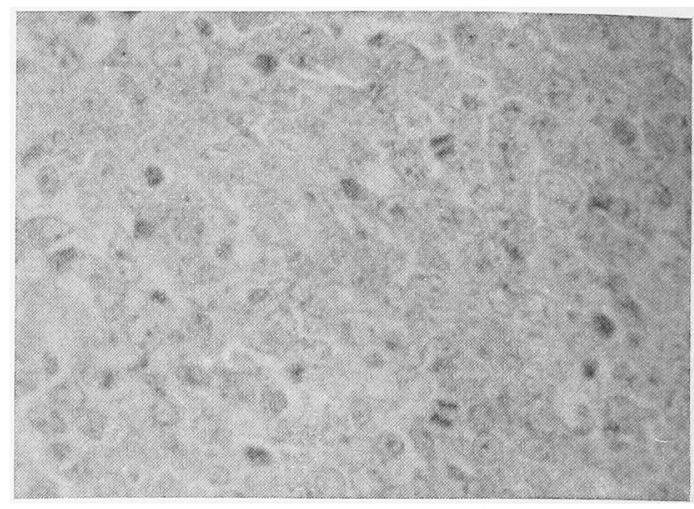

(H.E. 染色 $\times 400)$

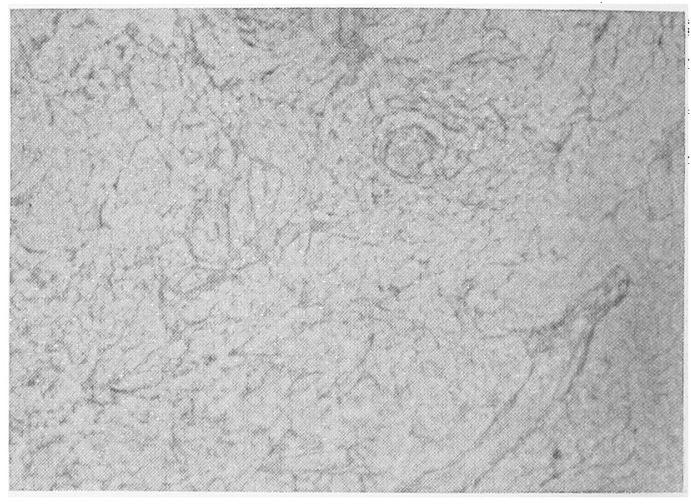

(Pap 染色 $\times 400)$

写真 4 病理組維所見

つ，胞体の之しい細胞が增殖しており，また核の分裂像 も見られる。細胞間は線維に囲まれている。これらの所 見から Reticulum cell sarcoma と誩断された（写真 3,4 参照).

処置および経過：表 2 に示すごとく，初診時未よび入 院時の検査を行なった５月日日，本尰湯の原発ないし， 転移柴の㭘索のため，本学放射線科括よび耳與咽喉科比 受診させ，さらに精密検査を行なったが，他榩器，組禨 には異常を認めなかった，治療法として， ${ }^{60} \mathrm{Co}$ 照射を 第 1 手段に選んだが，これは本腫場が，高い放射線感受 性を持つことから，まず同法の治療を先行した，5月 日第 1 回の ${ }^{60} \mathrm{Co}$ 照射を開始したが，放射線による口内 炎を出来るだけ防ぐ目的で，隔日照射，1回 $400 \mathrm{R}$ とし た．放射線照射による腫湯組織の変化は著明に現われ， $2000 \mathrm{R}$ 照射後では，今まで，腫偟組織に被われて見ら れなかった, $\frac{3.21 \mid}{3 \mid 3}$ の残根米が, 露出されて来, 著る しい維少が認められた，5月【日に ${ }^{80} \mathrm{Co}$ 照射終了， 総線量は $4000 \mathrm{R}$ で, 上下碩菌肉の腫溜は, 全く消失し た．その後口内炎等の炎症々状の回復を待って，6月 日，これら残存函の抜去扣よび，周罒軟組織の試適切除

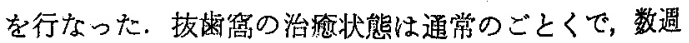


表 2 処置および経過

\begin{tabular}{|c|c|c|}
\hline 年.月.日 & 検 & 処 \\
\hline & 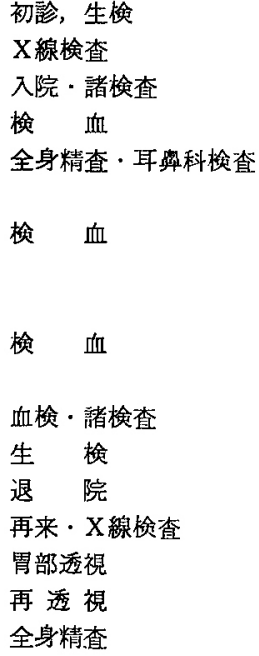 & 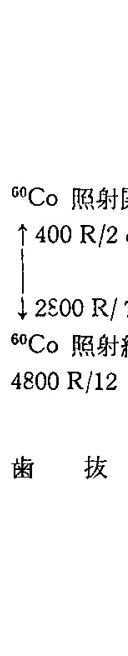 \\
\hline
\end{tabular}

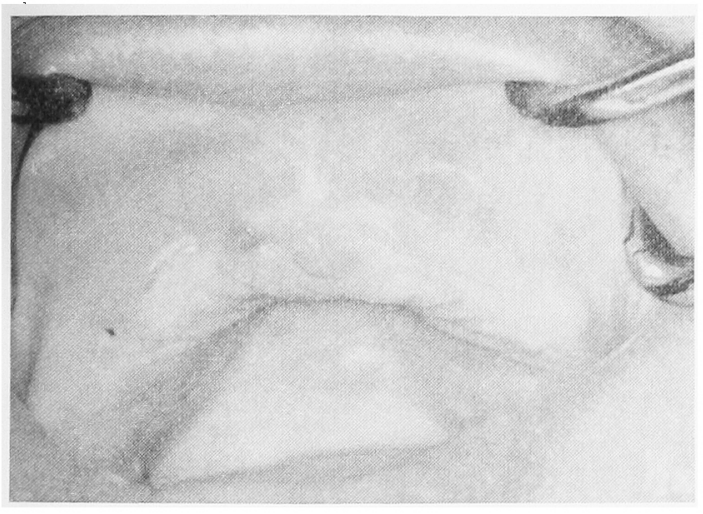

上顠

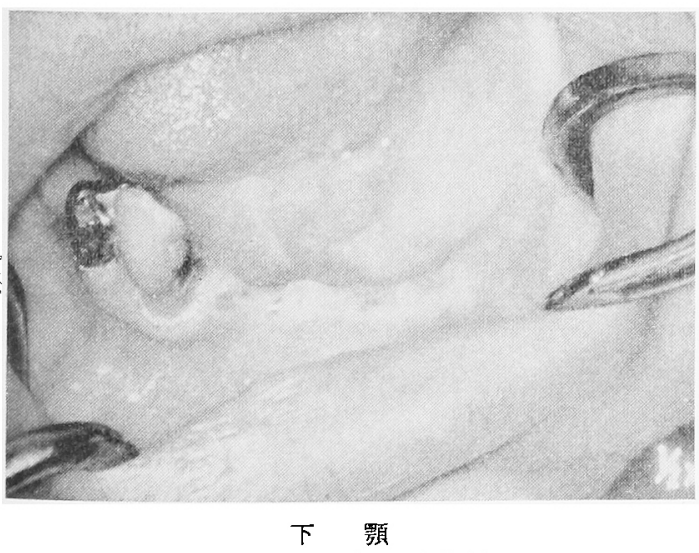

写真 5,6 涺院時口腔内所見

後，抜菌窝は正常歯肉によって閉鎖された。な和第回 2 目の試適切除による病理組織学的所見では，腫場細胞は
なく、形質細胞の浸潤を見る のみであった.

以後，予防照射として，顎 下, 頸部リンパ節への ${ }^{60} \mathrm{Co}$ 照射を考虑したが，患者の精 神状態悪く, 脳軟化症様状態 が見られたため，一時中止し これらの症状の回復を待つた め退院させ，外来患者として 経過を钼察した。な竹同症状 が脳への転移によるものかど らかを頭部X線撮影などによ り検索したが，転移を疑わせ る所見はなく、これは長年月 にわたる高血圧症のために出 現したものと考兄られた.

その後, 約 3 カ月にわたり

Followーup を行なったとこ ろ同腫䜿の再発傾向はなく, また全身への転移は認めなかった，写真 3 は 9 月 の口腔内写真である.

10 月初旬にいたり胃部の不快感亡，食慈不振を訴え たため，本学放射線科に入院乙，精密椧查の結果，胃底 部に腫䆩を疑わしめる所見あり，これが口腔内に原発し たと考えられる Reticulum ceil sarcoma の転移による

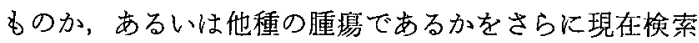
中である。

考案

細網肉腫の口然領域での発現率は，比較的多く，全肉 腫のらちの約 $45 \%$ を占めていると報告されている1).

また細網肉腫はリンパ性のものと骨髄性のものに分け られるが，リンパ性のものが大部分で，赤崎によれば， リンパ性 185 例に対し，赑髄性は，わずか数例であった と報告している：これらリンパ系由来のるの，あるいは 骨䯣性のももの他，他の組織上り原発するものもあるが, 非常にまれなるのと考えられている，本症例は上下顎の 雨肉に周時的に発生し，しかも所属リンパ節をはじめ， 頸部リンパ節，呂吸喉，口咽頭のリンパ装置などにも異 常を認めないところから，これら上下顎の雨肉に原発し たきわるてまれな症例と考えられる，外国では 1961 年 に $\mathrm{Cook}^{2)}$ が，口腔の組織より発生した報告を見るのみ で，わが国では渡辺らうの報告を見るにすぎない。

本腫瘄の発生原因は不明であるが，本症の埸合上下顎 の前歯部には残根㴹がありこの上に義雨が長年にわた り装着されていたことなとから，工藤らが指摘されて いる，残根の鋭緑による慢性刺戟があったものと考えら れ，これが腫痬発生に何らかの原因になっていたことは 容易に推察し得る. 
本腫瘍の治療法としては，まず放射線治療が第 1 亿あ げられ，梅垣 ${ }^{5}$ によれば，同腫渲の治療に必要な放射線 量は 1500 2500 R；4 週間の照射期間で完全に腫瘍が 消失すると報告されている. 本症例では腫演の大きさよ り計算し, 総線量 $4800 \mathrm{R}$ を照射したが, 第 2 回目の Biopsyにより腫瘍組織の完全消失を認めた。

予後については, 高い放射線感受性を示寸割りには, 一般に悪く, 大塚によれば大部分は 1 年以内に死亡し, 5 年以上の生存者はないと報告されている.これは本腫 瘍がリンパ節への転移を起しやすいばかりではなく, 中 心性に発生することからも予後を覀くしていると考えら れている(1. 本症も口腔内の原発部位には再発傾向は認 めなかったが，全身への転移について，今後も慎重に観 察を続けていく必要があるものと考えられる.
（稿を終えるに臨み，本学中央検查室副部長松原藤継助教授 に深謝致します.）

\section{文献}

1）宮崎吉夫他: 口腔病理学, 後編, 初版, 永末毒店, 京都, 1959 , p. 423.

2) Lucas, R. B. : Pathology of Tumours of the Oral Tissues, ed J. \& A. Churchill Ltd, 1964, 178.

3）增田敏雄他：多発性骨髄陣の 1 例. 口外誌 $15: 711969$.

4）工藤啓吾他：潾肉に認められた細網肉腫の 3 例について。 口科誌 $18: 8431969$.

5) Thoma, K. H. : Oral Surgery, ed Mosby Co, St Louis, 1963 , p. 813.

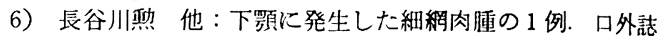
$16: 131970$.

7）土井 尚：靧下リンパ節に発生せる細網肉腫の 2 治験例. 口外誌 $16: 131970$. 